\title{
Judicial Procedure in Criminal Matters: Legal Provisions and Practical Issues
}

\section{Andrei Zarafiu}

Abstract: Approaching the judicial procedure within a common framework of criminal proceedings through analysis of the legal provisions and the case-law in criminal matters is a real challenge for the judicial authorities. First of all, criminal proceedings suppose the activity of finding the truth. The truth in criminal cases investigated and judged by the judicial bodies is gained only through pertinent, conclusive and genuine evidence. This means a multidisciplinary judicial approach in which the entire "actors" involved in criminal proceedings bring together skills and competences, procedures as well as legal instruments in order to obtain for them the expected results. The judicial skills of the judicial bodies are successfully provided in the case-law examination. In this regard, their competences are better understood within a common procedure in criminal proceedings, viewed under the general principle of solving the criminal cases beyond any reasonable doubt. The presented paper aims at finding appropriate ways of strengthening cooperation among practitioners in criminal matters in order to solve the criminal cases legally, as well as at providing real solutions to achieve the judicial truth in criminal cases that are investigated. The paper reviews the newer doctrinal instrument of the criminal procedure law, which comprises judicial institutions, special procedures as well as legal provisions discussed in a multidisciplinary context. Conclusive remarks are provided at the end of the presented paper, which refer to the most relevant aspects of the judicial procedure in criminal cases.

Key Words: Criminal Law; Criminal Matters; Criminal Cases; Legal Provisions; Case-law Examination; Solving Criminal Cases; Evidence; Investigation Procedure; Judicial Bodies; Judgment Phase; Romania.

\section{Introduction}

The judicial procedure, discussed in a multidisciplinary framework, is currently of a great importance for the justice in criminal matters, in particular for the criminal cases being either in the investigation phase or in the judgment phase of criminal proceedings. Indifferent of the criminal procedure involved, the ordinary procedure or the special one, the activi- 
ty of finding the truth is an imperative criterion for achieving the justice purpose by the judicial bodies. The manner in which the judicial bodies' competences interact with each other and the results gathered during the criminal proceedings depend on the high level of the justice system activity and, equally, on the acting factors which, generally speaking, favour the process of solving the criminal cases.

In a common framework of criminal proceedings, the judicial skills of solving the criminal cases in Romania are useful, as regulated by the Code of Criminal Procedure of Romania adopted by the Law No. 135 in year $2010 .{ }^{1}$ It harmonizes the general principles of criminal procedure law, also discussed by the doctrine in criminal matters with the European ones. Its current approach is analysed both from the doctrine's point of view as well as from the practical expectations, both in cases of offenses and serious crimes.

In this context, expressing the interest for multidisciplinary judicial skills in criminal proceedings, viewed in a common procedure, means a legal instrument of gathering results as well as a key factor of providing judicial decisions during the judgment phase, more particularly at the end of criminal proceedings.

The conclusive factors in the matter are expressly regulated by the provisions of the Code of Criminal Procedure of Romania, where a particular attention is being paid to the connection established between the judicial bodies and other professionals with competences in this area. They refer to the criminologists, the judicial bodies having competences in the investigation phase as well as to the forensic experts whose competences are carried out during the entire criminal proceedings. Their main purpose is to bring together information, skills and legal provisions in order to examine the criminal cases legally and multidisciplinary.

\section{Legal provisions and doctrinal references in criminal matters}

The general theory of criminal procedure has stated that, based on the common culture of the fundamental principles in criminal matters, ${ }^{2}$ the

1 See Law No. 135 of July 1, 2010, on the Code of Criminal Procedure [2010-07-01]. Official Journal of Romania, 2010, No. 486, into force from 7 February 2014.

2 In this regard, see MAURO, C. "Minimum" Procedural Rights in Judicial Cooperation Procedures. In: T. RAFARACI and R. BELFIORE, eds. EU Criminal Justice: Fundamental Rights, Transnational Proceedings and the European Public Prosecutor's Office [online]. $1^{\text {st }}$ ed. 
Article 82 of the Treaty on the Functioning of the European Union introduces standards of compromise in the matter of protection and procedural guarantees common to all the national systems in order to facilitate the judicial cooperation between the European Union Member States. In this field, the involvement of criminal justice at the European level was defined as a new concept of a global context. ${ }^{3}$

Basically, a new instrument in criminal matters is featured by the doctrinal and judicial issues, able to analyse the legal institutions of criminal proceedings in a new context, introduced by the entrance into force of the new Code of Criminal Procedure of Romania on 1 February 2014. It is about the criminal procedure law - a new doctrinal reference in criminal matters, published in year 2020.4 It has emphasized theoretical points of view, regarding the current legal provisions and juridical institutions of criminal procedure law, under the general framework stated by the Code of Criminal Procedure of Romania. At the same time, the constitutional references have been taken into account, while the legislator being accustomed to the Constitutional Court of Romania decisions which several times amended the provisions of the Code of Criminal Procedure of Romania and declared most of them unconstitutionally. ${ }^{5}$

Moreover, the general framework set up by the doctrine of criminal procedure law is supported by the jurisprudence in criminal cases, also examined both under the ordinary and the special criminal procedures, as regulated by the Code of Criminal Procedure of Romania. The case-law presentations are thus provided in the most important issues of the criminal institutions, such as those which deal with the following issues:

the concept of stopping the criminal proceedings under the legal basis, stated by the Article 16 para (1) letter i) of the Code of Criminal Procedure of Romania;

Cham: Springer, 2019, pp. 71-81 [cit. 2021-01-04]. ISBN 978-3-319-97319-7. Available at: https://doi.org/10.1007/978-3-319-97319-7_5.

3 See VERVAELE, J. A. E. European Criminal Justice in the European and Global Context. New Journal of European Criminal Law [online]. 2019, vol. 10, no. 1, pp. 7-16 [cit. 202101-04]. ISSN 2399-293X. Available at: https://doi.org/10.1177/2032284419840708.

4 For detailed legal institutions of criminal procedure law, see MAGHERESCU, D. Drept procesual penal: Partea generală: Partea specială. 1-a ed. București: Pro Universitaria, 2020, pp. 23-47. ISBN 978-606-26-1267-2.

5 See MAGHERESCU, D. Drept procesual penal: Partea generală: Partea specială. 1-a ed. București: Pro Universitaria, 2020, pp. 52-65. ISBN 978-606-26-1267-2. 
the parties and their procedural rights during the criminal proceedings;

the judicial bodies' material and territorial competences of administering the evidence as well as the preventive measures ordered by the court of law;

the absolute nullity of procedural acts carried out by an unqualified investigation body, which produces consequences during the preliminary courtroom procedure;

the three phases of criminal proceedings - investigation, judgment and execution of punishments - in cases of a definitive condemnation of defendants, according to their guilt, stated by the court of law.

From the structural point of view, the literature reviewed is divided into two parts. One of them is devoted to the general part of criminal procedure law, while another one to the special part of criminal procedure law. Both of them comprise chapters and sections disposed in conformity with the provisions of the Code of Criminal Procedure of Romania, the general part of which regulates the main judicial institutions, while the special part their applicability to practice.

In fact, it is about the doctrinal theory related to the nexus between the two parts of criminal procedure law, which highlights that the judicial institutions of criminal proceedings, provided by the general part of the Code of Criminal Procedure of Romania, fulfil their content and final purpose under the special provisions of the Code of Criminal Procedure of Romania.

The main traditional principles are comprehensively harmonized with the European ones, as a particular condition advanced by the European authorities even in the preliminary period of adhesion of Romania to the European Union. ${ }^{6}$ They refer to the following common principles of criminal procedure law, as they are regulated by the legislation in criminal matters in force:

a) The legality of criminal proceedings is viewed as the upper principle applied in the criminal cases investigated and judged according to the main provisions adopted by the Code of Criminal Procedure of Romania as well as under the constitutional provisions as well. The theory of legality is concordant to equality of arms, stated by the Article 6 para (1) of

6 See KOSTORIS, R. E. ed. Handbook of European Criminal Procedure [online]. $1^{\text {st }}$ ed. Cham: Springer, 2018, pp. 3-55 [cit.2021-01-04]. ISBN 978-3-319-72462-1. Available at: https://doi.org/10.1007/978-3-319-72462-1. 
the European Convention on Human Rights. From this point of view, the discussion could be focused around the idea of unbalancing powers that characterizes the investigation phase in which the prosecutor is entitled to use the entire procedural "arsenal" provided by the public function that features the public prosecutor office, while the defendant is entitled to use only the procedural rights regulated by the Code of Criminal Procedure of Romania, as it will be highlighted below. Nevertheless, in a benighted environment, the legislator has expressed the need for respecting the entire defendants' rights and interests during the criminal proceedings.

b) Dividing judicial functions is a newer judicial principle of criminal proceedings, implemented in the criminal justice once the new Code of Criminal Procedure of Romania entered into force. Regulated by the Article 3 thereof, the principle recognizes the activity of exercising four judicial functions of the criminal justice, as divided into the function of criminal prosecution, the function of disposing of fundamental rights and freedoms of persons during the investigation phase, the function of verifying the legality to send persons to trial as well as the function of judgment. All of these functions are exercised separately, in respect to the other judicial principles regulated by the Code of Criminal Procedure of Romania. Despite this rule, the legislator has provided an exception. It refers to the possibility to exercise the function of verifying the legality to send persons to trial, which is considered compatible with the function of judgment. ${ }^{7}$

c) Presumption of innocence has basically been implemented in the domestic legislation from the European provisions stated by the European Convention on Human Rights, which regulate the suspected person's innocence during the criminal proceedings under the Article 6 para (2) thereof. $^{8}$ On the one hand, according to the Article 23 para (11) of the Constitution of Romania, the defendant is being considered innocent until the definitive judicial decision pronounced by an independent court of

7 A derogation from the main rule of the Code of Criminal Procedure of Romania is granted by law which refers to the procedure of beginning the judgment under the Article 341 para (7) point 2 (c) of the Code of Criminal Procedure of Romania, as stated by the Article 3 para (3) thereof.

8 In accordance with the European provisions, the presumption of innocence is also regulated by the Article 4 para (1) of the Code of Criminal Procedure of Romania which states that "Any person is being considered innocent until the establishment of guilt by a definitive criminal decision". See, in this matter, Judgement of the Court of Law of Bacău Ref. No. 93 [2019]. 
law. For this reason, the defendant does not have the obligation to prove the innocence; in consequence, the obligation of submitting evidence in defense does not occur. Analysing the jurisprudence in case-law decisions pronounced by the courts of law in criminal matters, the principle of presumption of innocence, as it is regulated by the Article 4 of the Code of Criminal Procedure of Romania, involves two sides. One of them refers to the administration of evidence, while another one to its interpretation. This is because in the end of the judgment phase, the court of law is obliged to pronounce the judicial decision based on pertinent, conclusive and genuine evidence, resulted from the entire resources of evidence of the criminal case. Otherwise, the final aim of criminal proceedings will not be achieved and the judicial decision pronounced under such circumstances will be voidable.

d) Finding the truth in criminal cases is the main purpose of the criminal justice, namely of gathering the pertinent, conclusive and genuine evidence, in such a manner to be approved by the court of law. The doctrine in criminal matters has highlighted the objective feature of the truth ${ }^{9}$ that should be achieved in criminal proceedings. This feature must describe adequately the concordance between the criminal acts committed by the perpetrator and the aspects gathered by the court of law that will be reflected in the judicial decision. The judicial procedure in the criminal cases must imperatively be organized in a joint activity, in purpose for the court of law to find the truth - res judicata pro veritate habetur. The Romanian judicial activity in criminal matters offers the guarantee of the evidence system being based on conceptual guarantees, such as the liberty of evidence and means of evidence as well as their free appraisal.

e) $\mathrm{Ne}$ bis in idem is also viewed under the European Convention on Human Rights regulations, within the Article 7 thereof which states that any person cannot be convicted either for an action or an omissive act that is not an offence at the time of its committing, according to the domestic or international law. Under the Article 6 of the Code of Criminal Procedure of Romania, the principle has meant a measure of harmonizing the domestic legislation in criminal matters with the European Convention on Human Rights' requirements as well as with the European legislation, having organized around the European Union legislation compulsory for the Member States. The regulation of this principle means a real

9 See THEODORU, G. Tratat de Drept procesual penal. 2-a ed. București: Hamangiu, 2008, p. 83. ISBN 978-973-1836-86-7. 
guarantee that the legislator has submitted to the society, generally speaking, and stated in the Code of Criminal Procedure of Romania, regarding the judicial status which appears after the pronunciation of a definitive judicial decision in the criminal case.

f) Compulsory act of beginning and exercising criminal action features particularly the investigation phase of criminal procedure and is stipulated by the Article 7 of the Code of Criminal Procedure of Romania. It expresses an official act of the investigation bodies, stated by the Article 3 thereof, which provides that the judicial functions in criminal cases are exercised ex officio. This means that during the investigation phase of criminal proceedings the prosecutor has the exclusive right to beginning and to exercising the criminal action against the person who is suspected of having committed an offense. Consequently, the prosecution office must not be appraised of committing an offense in order for the current principle to be involved. Moreover, the prosecution bodies can begin the criminal action and can carry out any procedural act, according to the principle of compulsory act of beginning and exercising the criminal action.

g) Fair trial and solving the criminal cases in reasonable time provide that the judicial bodies are obliged to develop the investigation activity and the judgment within the framework of guaranteeing parties' procedural rights. ${ }^{10}$ It should be pointed out that Romania was several times condemned by the European Court of Human Rights because of the infringement of the Article 6 of the European Convention on Human Rights, especially in the beginning of the '90s, while the older Code of Criminal Procedure of Romania disadvantaged parties during the criminal proceedings. ${ }^{11}$ It was a serious drawback for the Romanian society entirely; this situation was remediated by the legislator at the time of adopting the new Code of Criminal Procedure of Romania. Moreover, it is considered

10 The principles of fair trial and solving the criminal cases in reasonable time are regulated by the Article 8 of the Code of Criminal Procedure of Romania which provides that "The judicial bodies are entitled to carry out both criminal investigation and judgment activities with the achievement of processual guarantees as well as the parties' and processual subjects' rights, in such a manner to state completely in due course the criminal actions, any innocent person to be under criminal liability, and any person who committed an offence to be punished according to criminal law provisions in reasonable time".

${ }^{11}$ See Case of Drăgănescu v. Romania [2008-09-30]. Judgement of the European Court of Human Rights, 2008, Application No. 29301/03; and Case of Bercaru v. Romania [200809-16]. Judgement of the European Court of Human Rights, 2008, Application No. 8870/ 02 . 
that the involvement of the principle of solving the criminal cases in reasonable time awards a larger certainty for the entire system of the criminal justice. From a practical point of view, the expedience of the criminal procedure is characterized by the fact that the criminal cases should be solved as rapidly as possible, with respect to the high level standards of fair trial and due process.

h) Right to freedom and safety guarantees that the defendant who was illegally arrested or deprived of liberty has the procedural right to compensation for the damage suffered, in accordance with the domestic law. The principle also leads to the right to information in a shortest period of time about the judicial reason of the arrest. On the one hand, the arrested defendant has the right to appeal against ordering such preventive measure of depriving of liberty; on the other hand, if defendant considers that such preventive measure was ordered illegally, then the qualified judicial bodies have the obligation to repealing measure. In these cases, the arrested defendant will immediately be discharged. Referring to this issue, the jurisprudence in criminal cases has emphasized unanimously that the judicial decision to arrest the defendant, which is not based on genuine evidence, is voidable. 12

i) Right to defense is the procedural right regulated by the Article 10 of the Code of Criminal Procedure of Romania for the defendant, the parties as well as the main processual subjects involved in criminal cases. The right to defense is practically supported by the right of defense which offers to parties the right to be assisted by a lawyer, either appointed by themselves or called ex officio by the judicial bodies under particular circumstances, stated by the Code of Criminal Procedure of Romania. It supposes that both the suspect and the defendant have the right to be informed on the criminal action they are accused of and on the judicial deeds' qualification. Moreover, the right to defense is also connected with the right to silence. In this regard, the judicial bodies must inform defendant about the right to declare nothing regarding the criminal case. In order to achieve the purpose of the right to defense, it should be exercised under the limit of a good faith. The feature of a due process, according to the European Court of Human Rights jurisprudence, states that the right of the defendant to participate personally in the criminal proceedings is not absolute. However, it is necessary in order for the

${ }^{12}$ See Decision of the High Court of Cassation and Justice of Romania Ref. No. 986/2018 [2018-12-28]. 
court of law to verify if the defendant is defended by a lawyer, either appointed by the defendant or called ex officio by the judicial bodies. ${ }^{13} \mathrm{An}$ imperative of the criminal procedure is that the judicial bodies must assure that the defendant is de facto defended by a lawyer during the criminal procedure.

j) Respecting the human dignity and private life occurs in criminal proceedings as a consequence of the other judicial principles presented above. ${ }^{14}$ The principle has a larger applicability, being extended over the three fundamental aspects of the individual's life. Thus, in the concept of the Code of Criminal Procedure of Romania, the respect to private life, the inviolability of domicile and the secrecy of correspondence are guaranteed. The infringement of exercising these rights is prohibited by criminal procedure law. Only one exception occurs under the legal conditions provided expressly by the legislator, as long as they appear as a necessary measure in a democratic society.

All of the above-stated principles, on the one hand, are corroborated each other and, one the other hand, subordinated comprehensively to the principle of free access to justice, ${ }^{15}$ having consequences in the field of pronouncing decisions in the criminal cases legally. ${ }^{16}$

Secondly, according to the Article 1 of the Code of Criminal Procedure of Romania, ${ }^{17}$ the rules of criminal procedure provide the judicial framework of criminal proceedings as well as those aspects which are judicially connected with a criminal case. In this circumstance, the doctrine has admitted that the rules of criminal proceedings establish relevant connection in a multidisciplinary framework, also defined as a structural one, due to the fact that they refer to the legal provisions which

${ }^{13}$ See Decision of the High Court of Cassation and Justice of Romania Ref. No. 238/A/2018 [2018-10-01].

14 The principle of respecting the human dignity and private life is regulated by the Article 11 of the Code of Criminal Procedure of Romania.

${ }^{15}$ According to the Article 21 of the Constitution of Romania, the persons are entitled to complain to justice for defending their rights, freedoms and legal interests. Any law should not infringe exercising this right.

${ }^{16}$ See PALMER, E., T. CORNFORD, A. GUINCHARD and Y. MARIQUE, eds. Access to Justice: Beyond the Policies and Politics of Austerity. $1^{\text {st }}$ ed. Oxford: Hart Publishing, 2016, pp. 1340. ISBN 978-1-84946-734-6.

${ }^{17}$ See Article 1 of the Title I. "Principles and Limits of Applying the Law of Criminal Procedure", regulated by the General Part of the Code of Criminal Procedure of Romania. 
regulate the state's right to punish defendants, on the one hand, and the means of achieving this right, on the other hand. ${ }^{18}$

Chronologically speaking, committing an offence generates the judicial bodies' competence to deploy the investigation instruments and to develop the criminal action into force, in accordance with the entire legal provisions regulated by the Code of Criminal Procedure of Romania. De iure, the function of investigation is compulsory as long as the prosecutor is obliged to exercise the criminal action ex officio, in cases in which there is sufficient evidence to prove that an offence was committed. This is a legal condition provided by the judicial provisions in criminal cases. Moreover, it has been stated that the prosecutor has the main role to intervene in cases in which a procedural act or activity is not justified. ${ }^{19}$

The doctrine in the criminal matters at the international level has also been involved in defining the special elements of criminal cases through stating appropriate definition for the theory of judicial institutions of criminal proceedings ${ }^{20}$ as well as performing the judicial authority through engaged judging practices. ${ }^{21}$

The second part of the criminal procedure law contains provisions regarding the special procedures, such as admitting a guilt agreement, juvenile justice, criminal liability of the legal entities, judicial cooperation in criminal matters and so on, where a particular attention is being paid to cases of serious crimes. ${ }^{22} \mathrm{~A}$ special interest occurs in relation to the special procedure of admitting a guilt agreement, regulated by the Code of Criminal Procedure of Romania at the first time in year 2014. The spe-

${ }^{18}$ See THEODORU, G. Tratat de Drept procesual penal. 2-a ed. Bucureşti: Hamangiu, 2008, p. 24. ISBN 978-973-1836-86-7.

${ }^{19}$ See NEAGU, I. Tratat de procedură penală: Partea generală. 3-a ed. București: Universul Juridic, 2013, p. 49. ISBN 978-606-673-075-4.

${ }^{20}$ See BERAIA, G. Freedom of Expression vs. Authority of Judiciary: Balancing the Competing Interests, Theory and Practice of National Courts, the European Court of Human Rights, the Supreme Court of the United States of America and the United Nations Human Rights Committee. Constitutional Law Review [online]. 2018, vol. 10, no. 11, pp. 48-66 [cit. 2021-01-04]. ISSN 1987-8540. Available at: http://clr.iliauni.edu.ge/wp-content/uploads/2020/05/Giorgi-Beraia-pp.48-66.pdf.

${ }^{21}$ See ROACH ANLEU, Sh. and K. MACK. Performing Judicial Authority in the Lower Courts [online]. $1^{\text {st }}$ ed. London: Palgrave Macmillan, 2017, pp. 3-9 [cit. 2021-01-04]. Palgrave Socio-legal Studies. ISBN 978-1-137-52159-0. Available at: https://doi.org/10.1057/978-1137-52159-0.

${ }^{22}$ See MAGHERESCU, D. Transnational Criminality in Europe and the Danger of Its Movement from East to West. Sintezis [online]. 2011, vol. 1, no. 3, pp. 165-189 [cit. 2021-0104]. ISSN 2334-7716. Available at: https://ssrn.com/abstract=2778616. 
cial procedure may only be advanced in cases in which the applied punishment is not the life imprisonment or more than 15 years imprisonment. The purpose of such legal provision is that of protecting the general interest of society from serious crimes, as a very spread phenomenon currently. ${ }^{23}$

This interest is also viewed upon the parties' rights during the special procedure, the prosecutor's role as well as his/her competence to sign the guilt agreement in such a manner not to be rejected by the court of law during the judgment phase of criminal proceedings. This means that the legislator has had in view one of the most important guarantees of the parties involved in the special procedure of admitting a guilt agreement.

Another judicial institution was presented around the judicial cooperation in criminal cases, also viewed under the European provisions, adopted at the European level and implemented in the domestic legislation in criminal matters, within the pre-established legal framework of adapting the community acquis to the national legislation in criminal matters. ${ }^{24}$

\section{Practical issues and case-law examination}

The analysis of judicial procedures in criminal matters is highlighted in particular case-law presentations, examined both in substantive criminal law and procedural criminal law. A new pertinent issue arises in the field of removing the evidence gathered illegally by the investigation bodies by the judge in preliminary courtroom procedure.

${ }^{23}$ See MAGHERESCU, D. Transnational Criminality in Europe and the Danger of Its Movement from East to West. Sintezis [online]. 2011, vol. 1, no. 3, pp. 165-189 [cit. 2021-0104]. ISSN 2334-7716. Available at: https://ssrn.com/abstract=2778616.

24 The procedure was imposed by the Law No. 157 of May 24, 2005, for the Ratification of the Treaty between the Kingdom of Belgium, the Czech Republic, the Kingdom of Denmark, the Federal Republic of Germany, the Republic of Estonia, the Hellenic Republic, the Kingdom of Spain, the French Republic, Ireland, the Italian Republic, the Republic of Cyprus, the Republic of Latvia, the Republic of Lithuania, the Grand Duchy of Luxembourg, the Republic of Hungary, the Republic of Malta, the Kingdom of the Netherlands, the Republic of Austria, the Republic of Poland, the Portuguese Republic, the Republic of Slovenia, the Slovak Republic, the Republic of Finland, the Kingdom of Sweden, the United Kingdom of Great Britain and Northern Ireland (Member States of the European Union) and the Republic of Bulgaria and Romania, Concerning the Accession of the Republic of Bulgaria and Romania to the European Union, Signed by Romania in Luxembourg on April 25, 2005 [2005-05-24]. Official Journal of Romania, 2005, No. 465. 
The jurisprudence in criminal cases is substantially analysed, being pertinently argued according to the legal provisions regulated by the Code of Criminal Procedure of Romania. In this respect, it has been provided that the judge of preliminary courtroom has proceeded to verify the legality of the indictment act issued by the prosecutor as well as the legality of administering the evidence during the investigation phase. ${ }^{25} \mathrm{In}$ this matter, the judge in preliminary courtroom procedure has observed the relative nullity of the ordinance of the invalidating act of beginning the investigation activity and subsequently has ordered to remove it from the case documents. Moreover, it has been ordered to remove the defendant witness's declarations from the pieces of evidence of the criminal case.

Consequently, the judge in preliminary courtroom procedure stated the legality of the investigating court of law by the prosecutor with the indictment act as well as "the legality of administering the other evidence and carrying out the other acts of investigation activity, regarding the defendant [...] for committing offence of attempting homicide, incriminated by the Article 32 of the Penal Code, related to the Article 188 para (1) and para (2) of the Penal Code and ordered the beginning of judgment". ${ }^{26}$

The literature review is also focused on the last modifications of the Code of Criminal Procedure of Romania, disposed by the Constitutional Court of Romania, which amended it several times for the infringement of the Constitution of Romania. ${ }^{27}$ The practical issues are then connected to the major scope of legislation in criminal cases, which consists in adapting the rules provided by the Code of Criminal Procedure of Romania to the fundamental ones, regulated by the Constitution of Romania.

From a doctrinal point of view, it has also been emphasized that the jurisprudence in criminal cases plays a significant role, being connected to the constitutional provisions, in particular to the decisions pronounced by the Constitutional Court of Romania.

${ }^{25}$ See Judgement of the Court of Law of Covasna Ref. No. 16 [2018-06-25] in MAGHERESCU, D. Drept procesual penal: Partea generală: Partea specială. 1-a ed. București: Pro Universitaria, 2020, pp. 273-274. ISBN 978-606-26-1267-2.

${ }^{26}$ See Judgement of the Court of Law of Covasna Ref. No. 16 [2018-06-25] in MAGHERESCU, D. Drept procesual penal: Partea generală: Partea specială. 1-a ed. București: Pro Universitaria, 2020, pp. 273-274. ISBN 978-606-26-1267-2.

${ }^{27}$ See Constitution of Romania, amended by Law No. 429 [2003-09-18]. Official Journal of Romania, 2003, No. 669. 
Regarding the evidence administered illegally, the defendant has required from the judge in preliminary courtroom procedure to return the criminal case back to the Prosecutor Office as well as to establish the nullity of the records on intercepting conversations. The main argument was that the procedural act has been carried out by other state authorities than the judicial ones; therefore, this activity should be featured by the nullity of such procedural acts, according to the Constitutional Court Decision No. 51 of year $2016 .{ }^{28}$

In fact, the defendant admitted that during the investigation phase of criminal proceedings some actions of intercepting communications were approved by the court of law, but they were not carried out by the judicial bodies, which is the fact that brings about the sanction of nullity of procedural acts carried out under these circumstances. Considering all these aspects, the evidence gathered by the judicial bodies through the procedural means of technical surveillance is null. ${ }^{29}$

It is appreciated that, from the point of view of the evidence administered during the investigation phase, the main purpose of the preliminary courtroom procedure lies in the aspect of verifying the respect to the principle of legality. This aspect supposes the application of proceeding rules of administering the evidence, but not the analysis of their content from the point of view of rationality, pertinence and conclusive features - aspects that involve the background of the case which is decided by the judge within the judicial decision pronounced.

Regarding the procedure of appealing the legality of seizing court of law and administering the evidence, the defendant may not invoke the reason that the investigation bodies did not take into account the participation of other persons in committing criminal acts. The court of law has proceeded so, under these circumstances, due to the fact that the Article 328 of the Code of Criminal Procedure of Romania does not regulate the obligation of analysing the criminal participation of other persons. Moreover, the procedural institution of extending the criminal action by

${ }^{28}$ See Judgement of the Court of Law of Iași Ref. No. 18 [2017-02-15] in MAGHERESCU, D. Drept procesual penal: Partea generală: Partea specială. 1-a ed. București: Pro Universitaria, 2020, pp. 125-127. ISBN 978-606-26-1267-2.

${ }^{29}$ See Judgement of the Court of Law of Iași Ref. No. 18 [2017-02-15] in MAGHERESCU, D. Drept procesual penal: Partea generală: Partea specială. 1-a ed. București: Pro Universitaria, 2020, pp. 125-127. ISBN 978-606-26-1267-2. 
the judge during the judgment phase is not regulated by the Code of Criminal Procedure of Romania any more. ${ }^{30}$

In this matter, Article 371 of the Code of Criminal Procedure of Romania limits the object of judgment to deeds and persons provided by the indictment act, instead of the aspect of deeds' judicial qualification. In this case, the court of law is entitled to change the deeds' judicial qualification, under the Article 386 thereof. Nevertheless, it is limited to defendants and criminal acts inserted in the indictment act, submitted by the prosecutor.

The practice of an illegal activity in the investigation phase of criminal proceedings was viewed as a serious infringement of the Article 6 of the European Convention on Human Rights provisions as well as of the European Court of Human Rights jurisprudence, which advanced the rule on due process. From a domestic law perspective, Article 21 para (3) of the Constitution of Romania, corroborated with the Article 8 of the Code of Criminal Procedure of Romania, imposes an equilibrium between the defense and accusation, as equality of arms in criminal cases, as well as the idea of a fair trial, including principles of both the general interests and the individual interests.

Consequently, the elements of due process should be found in any procedure, ordinary or special, during the entire criminal proceedings, not just in the judgment phase, but in the investigation phase as well. It particularly means a large spectrum of procedural guarantees, granted by the judicial bodies both for the defendants and all the involved parties in criminal cases.

\section{Conclusions}

Approaching the legal institutions of criminal procedure law within the criminal proceedings in Romania has changed the manner in which the criminal cases were solved after the entrance into force of the new Code of Criminal Procedure of Romania in year 2014. A new vision has been created, in accordance with the European provisions, stated both by the European Convention on Human Rights and the European Court of $\mathrm{Hu}$ man Rights jurisprudence.

\footnotetext{
${ }^{30}$ See Decision of the High Court of Cassation and Justice of Romania Ref. No. 211/A/2017
} [2017-06-12]. 
The involvement of the doctrine in the field of the criminal justice means, from a theoretical perspective, a necessary instrument of balancing the judicial bodies' skills and the legal institutions, transferred into the finalization of criminal proceedings.

A new theory of achieving the functions of criminal proceedings by legal provisions stipulated expressly by the Code of Criminal Procedure of Romania is more than necessary. This means that in a common framework of criminal matters the coexistence of those legal means of criminal procedure, which are regulated by the Code of Criminal Procedure of Romania, comes to argue the theoretical background along with the practical expectations.

The Romanian justice system in criminal matters is then featured by several topics, well-grounded and implemented in practice. Jurisprudence is, in this context, one of the most important instruments for balancing the parties' procedural rights and judicial skills in criminal cases.

All these aspects considered, the literature's content offers guidance both for students and practitioners who would like to deepen their knowledge in the field of criminal procedure law, including the newer judicial institutions in the European context.

\section{References}

BERAIA, G. Freedom of Expression vs. Authority of Judiciary: Balancing the Competing Interests, Theory and Practice of National Courts, the European Court of Human Rights, the Supreme Court of the United States of America and the United Nations Human Rights Committee. Constitutional Law Review [online]. 2018, vol. 10, no. 11, pp. 48-66 [cit. 2021-01-04]. ISSN 1987-8540. Available at: http://clr.iliauni. edu.ge/wp-content/uploads/2020/05/Giorgi-Beraia-pp.48-66.pdf.

Case of Bercaru v. Romania [2008-09-16]. Judgement of the European Court of Human Rights, 2008, Application No. 8870/02.

Case of Drăgănescu v. Romania [2008-09-30]. Judgement of the European Court of Human Rights, 2008, Application No. 29301/03.

Constitution of Romania, amended by Law No. 429 [2003-09-18]. Official Journal of Romania, 2003, No. 669.

Decision of the Constitutional Court of Romania Ref. No. 51/2016 [201602-16]. 
Decision of the High Court of Cassation and Justice of Romania Ref. No. 211/A/2017 [2017-06-12].

Decision of the High Court of Cassation and Justice of Romania Ref. No. 238/A/2018 [2018-10-01].

Decision of the High Court of Cassation and Justice of Romania Ref. No. 986/2018 [2018-12-28].

European Convention on Human Rights.

Judgement of the Court of Law of Bacău Ref. No. 93 [2019].

Judgement of the Court of Law of Covasna Ref. No. 16 [2018-06-25].

Judgement of the Court of Law of Iași Ref. No. 18 [2017-02-15].

KOSTORIS, R. E. ed. Handbook of European Criminal Procedure [online]. $1^{\text {st }}$ ed. Cham: Springer, 2018. 445 p. [cit. 2021-01-04]. ISBN 978-3319-72462-1. Available at: https://doi.org/10.1007/978-3-319-724 62-1.

Law No. 135 of July 1, 2010, on the Code of Criminal Procedure [2010-0701]. Official Journal of Romania, 2010, No. 486, into force from 7 February 2014.

Law No. 157 of May 24, 2005, for the Ratification of the Treaty between the Kingdom of Belgium, the Czech Republic, the Kingdom of Denmark, the Federal Republic of Germany, the Republic of Estonia, the Hellenic Republic, the Kingdom of Spain, the French Republic, Ireland, the Italian Republic, the Republic of Cyprus, the Republic of Latvia, the Republic of Lithuania, the Grand Duchy of Luxembourg, the Republic of Hungary, the Republic of Malta, the Kingdom of the Netherlands, the Republic of Austria, the Republic of Poland, the Portuguese Republic, the Republic of Slovenia, the Slovak Republic, the Republic of Finland, the Kingdom of Sweden, the United Kingdom of Great Britain and Northern Ireland (Member States of the European Union) and the Republic of Bulgaria and Romania, Concerning the Accession of the Republic of Bulgaria and Romania to the European Union, Signed by Romania in Luxembourg on April 25, 2005 [2005-05-24]. Official Journal of Romania, 2005, No. 465.

MAGHERESCU, D. Drept procesual penal: Partea generală: Partea specială. 1-a ed. Bucureşti: Pro Universitaria, 2020. 412 p. ISBN 978-606-261267-2. 
MAGHERESCU, D. Transnational Criminality in Europe and the Danger of Its Movement from East to West. Sintezis [online]. 2011, vol. 1, no. 3, pp. 165-194 [cit. 2021-01-04]. ISSN 2334-7716. Available at: https:// ssrn.com/abstract $=2778616$.

MAURO, C. "Minimum" Procedural Rights in Judicial Cooperation Procedures. In: T. RAFARACI and R. BELFIORE, eds. EU Criminal Justice: Fundamental Rights, Transnational Proceedings and the European Public Prosecutor's Office [online]. $1^{\text {st }}$ ed. Cham: Springer, 2019, pp.71-81 [cit. 2021-01-04]. ISBN 978-3-319-97319-7. Available at: https://doi.org/10.1007/978-3-319-97319-7_5.

NEAGU, I. Tratat de procedură penală: Partea generală. 3-a ed. București: Universul Juridic, 2013. 715 p. ISBN 978-606-673-075-4.

PALMER, E., T. CORNFORD, A. GUINCHARD and Y. MARIQUE, eds. Access to Justice: Beyond the Policies and Politics of Austerity. $1^{\text {st }}$ ed. Oxford: Hart Publishing, 2016. 311 p. ISBN 978-1-84946-734-6.

ROACH ANLEU, Sh. and K. MACK. Performing Judicial Authority in the Lower Courts [online]. $1^{\text {st }}$ ed. London: Palgrave Macmillan, 2017. 234 p. [cit. 2021-01-04]. Palgrave Socio-legal Studies. ISBN 978-1137-52159-0. Available at: https://doi.org/10.1057/978-1-137-521 59-0.

THEODORU, G. Tratat de Drept procesual penal. 2-a ed. Bucureşti: Hamangiu, 2008. 1060 p. ISBN 978-973-1836-86-7.

Treaty on the Functioning of the European Union.

VERVAELE, J. A. E. European Criminal Justice in the European and Global Context. New Journal of European Criminal Law [online]. 2019, vol. 10, no. 1, pp. 7-16 [cit. 2021-01-04]. ISSN 2399-293X. Available at: https://doi.org/10.1177/2032284419840708.

Assoc. Prof. Andrei Zarafiu, Ph.D.

Faculty of Law University of Bucharest Mihail Kogălniceanu Blvd. 36-46 050107 Bucharest Romania andrei.zarafiu@drept.unibuc.ro 